\title{
I. PALEOCEANOGRAPHICALLY CONTROLLED ULTRASTRUCTURAL VARIATION IN NEOGLOBOQUADRINA PACHYDERMA (EHRENBERG) AT DSDP SITE 284, SOUTH PACIFIC
}

\author{
M.S. Srinivasan and J.P. Kennett, Graduate School of Oceanography, \\ University of Rhode Island, Kingston, Rhode Island
}

\begin{abstract}
Variation in surface ultrastructure has been examined with the scanning electron microscope in 12 populations of Neogloboquadrina pachyderma from the late Miocene to the Holocene or latest Pleistocene at DSDP Site 284 in the cool subtropical water mass of the South Pacific. Fifty specimens were examined in each sample allowing quantitative analysis of the trends. Two main ultrastructural types are readily recognized: reticulate forms with relatively unthickened, pitted, microcrystalline surface and more thickened crystalline forms with test covered by distinct euhedral calcite rhombs. Intermediate forms link these two types.

Oscillations in the ratio of reticulate to crystalline ultrastructure in populations of $N$. pachyderma closely coincide with substantial fluctuations in surface water masses during the Cenozoic recorded by Kennett and Vella (1975). Reticulate forms are dominant during warm-water episodes; crystalline forms are dominant during cooler water episodes. Variation in ultrastructure with $N$. pachyderma thus provides a valuable new tool for late Cenozoic paleoceanographic analysis that may also be applicable within other forms of planktonic foraminifera. Particularly severe climatic cool episodes are shown by this method to have occurred in the New Zealand region during the latest Miocene, the late Pliocene, and during the Pleistocene, thus supporting previous interpretations based on planktonic foraminifera.

Ultrastructural differences reflect the degree of crystalline thickening with reticulate ultrastructure preceding the formation of crystalline ultrastructure. The degree of crystalline thickening is thus partly water-mass related and is not, as previous work implies, related only to ontogenetic change within individuals taking place with increased water depth.
\end{abstract}

\section{INTRODUCTION}

Important advances have been made in foraminiferal research during the last decade through the application of the scanning electron microscope (SEM) for surface ultrastructural studies of foraminifera. The few papers on surface ultrastructural characteristics of planktonic foraminifera using the SEM show that ultrastructure is of considerable significance in the classification of planktonic foraminifera (Lipps, 1966; Tappan and Lipps, 1966; Bartlett, 1967; McGowran, 1968; Collen and Vella, 1973; Cifelli, 1973; Walker and Vilks, 1973; and Vilks and Walker, 1974).

Ultrastructural variation also appears to have much potential in paleoceanographic studies. In a pioneering contribution, Wiles (1967) showed that changes in pore density in Neogloboquadrina dutertrei are related to Pleistocene paleotemperature oscillations recorded in deep-sea cores with high pore concentrations characteristic of warm episodes. This was later confirmed by Frerichs et al. (1972) and Srinivasan and Kennett (1975). A firm basis for the observations of
Wiles was provided by Bé (1968) who showed that changes in pore diameters and test porosities (pore space per unit area) in Recent planktonic foraminiferal species are related to water-mass changes. Before now, the potential value of ultrastructural variations for paleooceanographic studies has not been examined other than those variations involving pore density and porosity. The significance of ultrastructural variation within planktonic foraminifera for recognizing phenotypic variation and phylogeny was first applied by Srinivasan and Kennett $(1974,1975)$ who showed that relationships exist between surface ultrastructural characteristics of forms with the Neogloboquadrina dutertrei plexus and changing water-mass conditions. Kennett and Srinivasan (in press) have also carried out detailed SEM examination of the test surface of $N$. pachyderma (Ehrenberg) from different water masses during the late Cenozoic and have recognized two principal types of surface ultrastructure that are independent of coiling direction.

The purpose of this paper is to describe surface ultrastructural variation in $N$. pachyderma populations 
throughout the late Miocene to Pleistocene sequence cored at Site 284 and to show that the observed variation is related to independently determined paleoceanographic oscillations.

Site $284\left(40^{\circ} 30.48^{\prime} \mathrm{S} ; 167^{\circ} 40.81^{\prime} \mathrm{E}\right)$ is located in the present-day cool subtropical water mass, $400 \mathrm{~km}$ north of the Subtropical Convergence (Figure 1). Two holes were drilled, 284 continuously cored to a depth of 208 meters and $284 \mathrm{~A}$ to obtain three 9-meter sections lost in 284. Planktonic foraminifera are abundant throughout this relatively shallow-water site $(1068 \mathrm{~m})$ and show very little evidence of dissolution. Planktonic foraminiferal biostratigraphy, population statistics and paleoceanographic evaluation of this site are presented in a companion paper by Kennett and Vella (1975), while oxygen isotope analyses of samples of the benthonic foraminiferal genus Uvigerina are presented by Shackleton and Kennett (1975).

A relatively detailed chronology has been established by Kennett and Vella (1975) by correlation with paleomagnetically dated late Cenozoic sequences in New Zealand (Kennett et al., 1971; Kennett and Watkins, 1974). The sequence represents 6 m.y. of virtually continuous deposition of calcareous ooze, although much of the Pleistocene is missing due to a disconformity. Kennett and Vella (1975) show that frequent oscillations in the cool-water foraminifer $N$. pachyderma appear to reliably reflect paleoclimatic change. Oscillations in the frequency of this species mark particularly cool episodes during the latest Miocene and earliest Pliocene (equivalent to the New Zealand Kapitean-early Opoitian stages), during the late Pliocene (Waipipian Stage), and a brief cooling episode during the early Pleistocene (Kennett and Vella, 1975). Warmer episodes occur during the late Miocene late Tongaporutuan Stage, throughout much of the Pliocene Opoitian Stage, and at several intervals during the Pleistocene. Paleoclimatic interpretation based on the foraminiferal faunal changes are closely supported by changes in oxygen isotopes (Shackleton and Kennett, 1975).

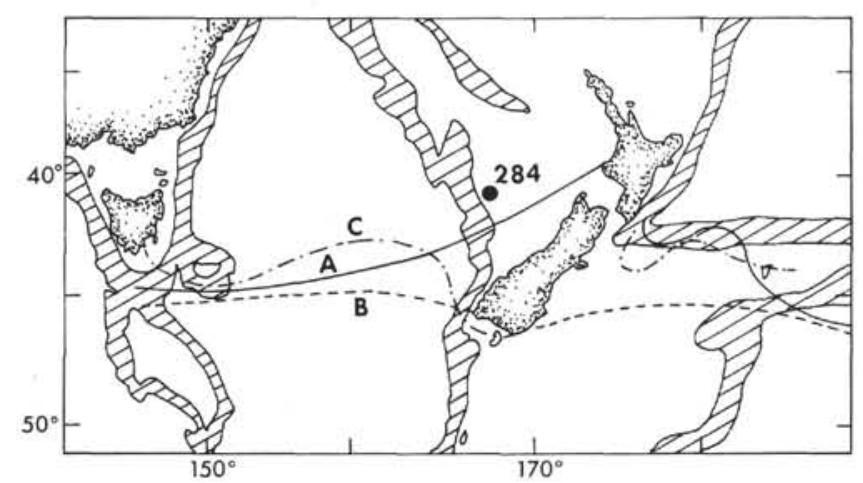

Figure 1. Location of DSDP Site 284 on the Challenger Plateau showing (a) the trend of the subtropical convergence according to Deacon (1937); (b) the southern limit of a zone of mixed waters which Fleming (1944) described between subantarctic and subtropical water; and $(c)$ the general form of the subtropical convergence after Garner (1954).

\section{METHODS OF STUDY}

Twelve samples of $N$. pachyderma were examined from the late Miocene to Recent (Figure 2). The samples were selected from both cool and warm intervals (Kennett and Vella, 1975) to determine if ultrastructural changes within this species are related to paleoceanographic oscillations. The ultrastructure of 50 randomly selected specimens of $N$. pachyderma from each sample were examined using the SEM (Cambridge S4). In addition, coiling ratios and percentages of kummerform and normalforms were noted for each sample examined. Picking of 50 individuals normally takes $1 \mathrm{hr}$, the mounting of these specimens on two stubs a further hour, and examination with the SEM $3 \mathrm{hr}$ (Table 1).

\section{SURFACE ULTRASTRUCTURAL TYPES}

Two principal types of surface ultrastructures exist in $N$. pachyderma in the Site 284 sequence: reticulate and crystalline. In addition, variable proportions occur of an intermediate form.

\section{Reticulate Surface UItrastructure}

The test in these forms has a microcrystalline surface with distinct pore pits (Plate 1, Figures 4-9), which are shallow to deep and are surrounded by polygonal ridges of varying heights. The ridges are normally continuous, but occasionally they are discontinuous on the final chamber and appear as discrete tubercles (Plate 1, Figure 5). Individual pore pits usually enclose a single pore, but occasionally more than one pore may occur (Plate 1, Figure 7). The pores are circular in shape and are located in the center of a flat to gently sloping base of the pore pit which varies from equidimensional to elongate depending on the number of enclosed pores. The interpore area is a smooth, microcrystalline surface without any discernible rhombohedral crystals even at $\times 5000$ magnification. Some test thickening occurs by microcrystalline accumulation on ridges of earlier chambers. Even in these specimens, the test remains thinner than individuals with crystalline surface ultrastructure. Some individuals show secondary spikelike tubercles on the earlier chambers of the last whorl just inside the aperture. Forms from warm intervals have shallow, open pore pits with polygonal ridges of lower relief than forms from cool intervals, which have deep pore pits separated by thickened ridges of high relief.

\section{Crystalline Surface Ultrastructure}

The test in these forms in covered almost entirely by large euhedral calcite crystals greater than $2 \mu \mathrm{m}$ in length. On the final and penultimate chambers the calcite crystals cluster around the pores (Plate 2, Figure 8 ) while on the antepenultimate and earlier chambers the rhombohedral crystals (sharing a common c-axis) develop penetration twins giving rise to a stellate structure (Plate 2, Figure 9). Crystal faces are normally marked by growth facets (Plate 2, Figure 9). As the euhedral calcite rhombs increase in size on successfully earlier chambers, there is corresponding reduction in the number and size of the pores which are almost obscured on earlier chambers as a result of increased crystallinity 


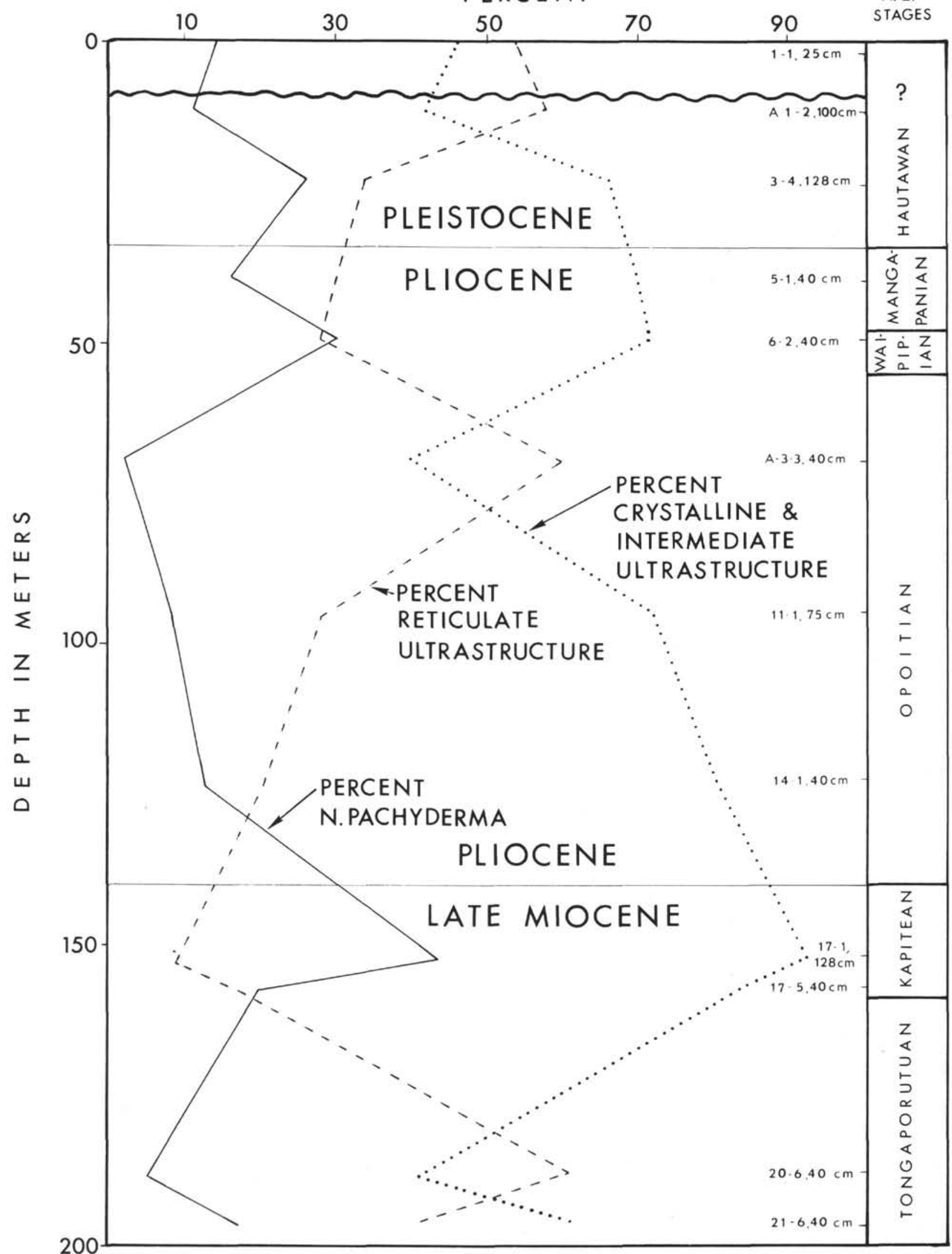

Figure 2. Percent fluctuations of Neogloboquadrina pachyderma (after Kennett and Vella, 1975) and surface ultrastructural variations of $\mathrm{N}$. pachyderma in the late Miocene to Pleistocene sequence cored at DSDP Site 284. High frequencies of $\mathrm{N}$. pachyderma represent cool intervals; low frequencies represent warm intervals. Ultrastructural characteristics based on examination using the scanning electron microscope of 50 specimens in each of the samples shown at right. Note similarity in curves of percent N. pachyderma and reticulate ultrastructure. New Zealand late Cenozoic stages shown at right have been correlated by Kennett and Vella (1978). Pleistocene disconformity shown near top of sequence. 
TABLE 1

Data for Neogloboquadrina pachyderma at Site 284 and Ages of Samples

\begin{tabular}{|c|c|c|c|c|c|c|c|c|}
\hline 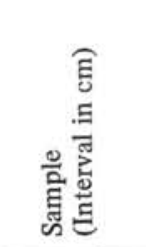 & \& & 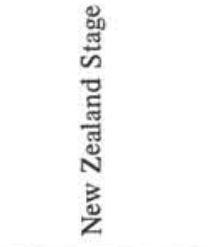 & 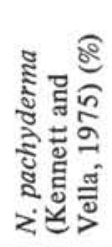 & 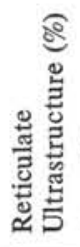 & 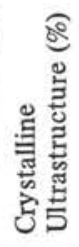 & 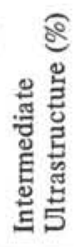 & 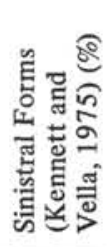 & 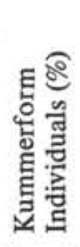 \\
\hline $1-1,25$ & & $\begin{array}{l}\text { Pleistocene or } \\
\text { Holocene }\end{array}$ & 14 & 54 & 16 & 30 & 8 & 72 \\
\hline $1 \mathrm{~A}-2,100$ & Pleistocene & Hautawan & 11 & 58 & 12 & 30 & 28 & 88 \\
\hline $3-4,128$ & & Hautawan & 26 & 34 & 12 & 54 & 10 & 70 \\
\hline $5-1,40$ & & Mangapanian & 16 & 30 & 6 & 64 & 15 & 84 \\
\hline $6-2,40$ & & Waipipian & 30 & 28 & 18 & 54 & 49 & 92 \\
\hline $3 \mathrm{~A}-3,40$ & & Opoitian & 2 & 60 & 10 & 30 & 55 & 94 \\
\hline $11-1,75$ & Pliocene & Opoitian & 8 & 28 & 46 & 26 & 79 & 78 \\
\hline $14-1,40$ & & Opoitian & 12 & 20 & 36 & 44 & 83 & 78 \\
\hline $17-1,128$ & & Kapitean & 43 & 8 & 50 & 42 & 93 & 92 \\
\hline $17-5,40$ & & Kapitean & 19 & 16 & 42 & 42 & 91 & 82 \\
\hline $20-6,40$ & Late Miocene & Tongaporutuan & 4 & 60 & 10 & 30 & 77 & 88 \\
\hline $21-6,40$ & & Tongaporutuan & 16 & 40 & 18 & 42 & 84 & 78 \\
\hline
\end{tabular}

(Plate 2, Figure 5). Tests are more thickened than in reticulate forms.

\section{Intermediate Forms}

Individuals that have crystalline surfaces on all except the final and penultimate chamber which are reticulate microcrystalline, link the two types of ultrastructures. As already demonstrated by Bé (1960) and Hunkins et al. (1971), this shows that reticulate surface structure is an initial ultrastructure preceding calcite crust formation of the test. The fact that gradual decrease in crystallinity generally occurs in successively younger chambers also demonstrates that crystalline thickening of the test is produced by the foraminifer itself rather than by any diagenetic process.

Intermediate forms more closely resemble crystalline forms because of crystalline thickening on most chambers and are hence grouped together for the purpose of this discussion (Figures 2 and 3 ).

\section{RELATION BETWEEN ULTRASTRUCTURAL OSCILLATIONS IN N. PACHYDERMA AND PALEOCEANOGRAPHIC CHANGE}

Large fluctuations in the ratio of reticulate to crystalline-intermediate ultrastructure occur throughout the sequence (Figures 2 and 3). Very close relations exist between ultrastructural variation and paleoceanographic oscillations as revealed by the changes in the frequency of $N$. pachyderma (Figure 2). The percentage of reticulate forms is reciprocal to percent fluctuations in $N$. pachyderma (except in the case of latest Pliocene sample-5-1, $40 \mathrm{~cm}$ ), with low percentages of reticulate forms occurring during cool episodes when frequencies of $N$. pachyderma are high (Figure 2). Warm episodes correspond to intervals with high frequencies of reticulate forms or low frequencies of crystallineintermediate forms.

High frequencies of forms with reticulate ultrastructure occur during the early late Miocene (Tongaporu- tuan Stage), the middle Pliocene (late Opoitian Stage), and during part of the Pleistocene. Frequencies of $N$. pachyderma with crystalline surface ultrastructure are high during the latest Miocene and basal Pliocene (Kapitean and lower Opoitian stages) and during the late Pliocene and the earliest Pleistocene (Figure 2).

Because higher frequencies of individuals with reticulate ultrastructure correspond with warm episodes, while high frequencies of forms with crystalline ultrastructure correspond with cooler intervals, we propose that this relation represents a valuable additional paleoceanographic index. The most severe cooling episode reflected by ultrastructural characteristics occur during the latest Miocene and earliest Pliocene (Kapitean-early Opoitian stages) with a less severe cooling suggested during the late Pliocene and earliest Pleistocene.

Coiling-ratio changes in $N$. pachyderma of late Miocene to Recent sequences have been utilized by various investigators for paleoclimatic analyses (Ericson, 1959; Bandy, 1959, 1960; Jenkins, 1967; Ingle, 1967). Sinistral populations have been considered to be dominant in cool-water masses and dextral populations in warmer water masses. Kennett and Vella (1975) from analyses of temperate to tropical late Cenozoic sequences in the South Pacific have shown, however, that coiling-ratio oscillations in $N$. pachyderma are of no value for paleoceanographic interpretations within the late Miocene and early Pliocene although the method appears to be valid for younger sequences. It seems that $N$. pachyderma inherited sinistral coiling from its ancestor Globorotalia continuosa in the early late Miocene (Jenkins, 1967) and did not adapt to watermass-related coiling-ratio changes until the Pliocene (Kennett and Vella, 1975). This is supported by the ultrastructural variations at Site 284, which show little relation to coiling-ratio changes (Figure 3). For instance, relatively low frequencies of $N$. pachyderma and high percentages of forms with reticulate ultrastructure 


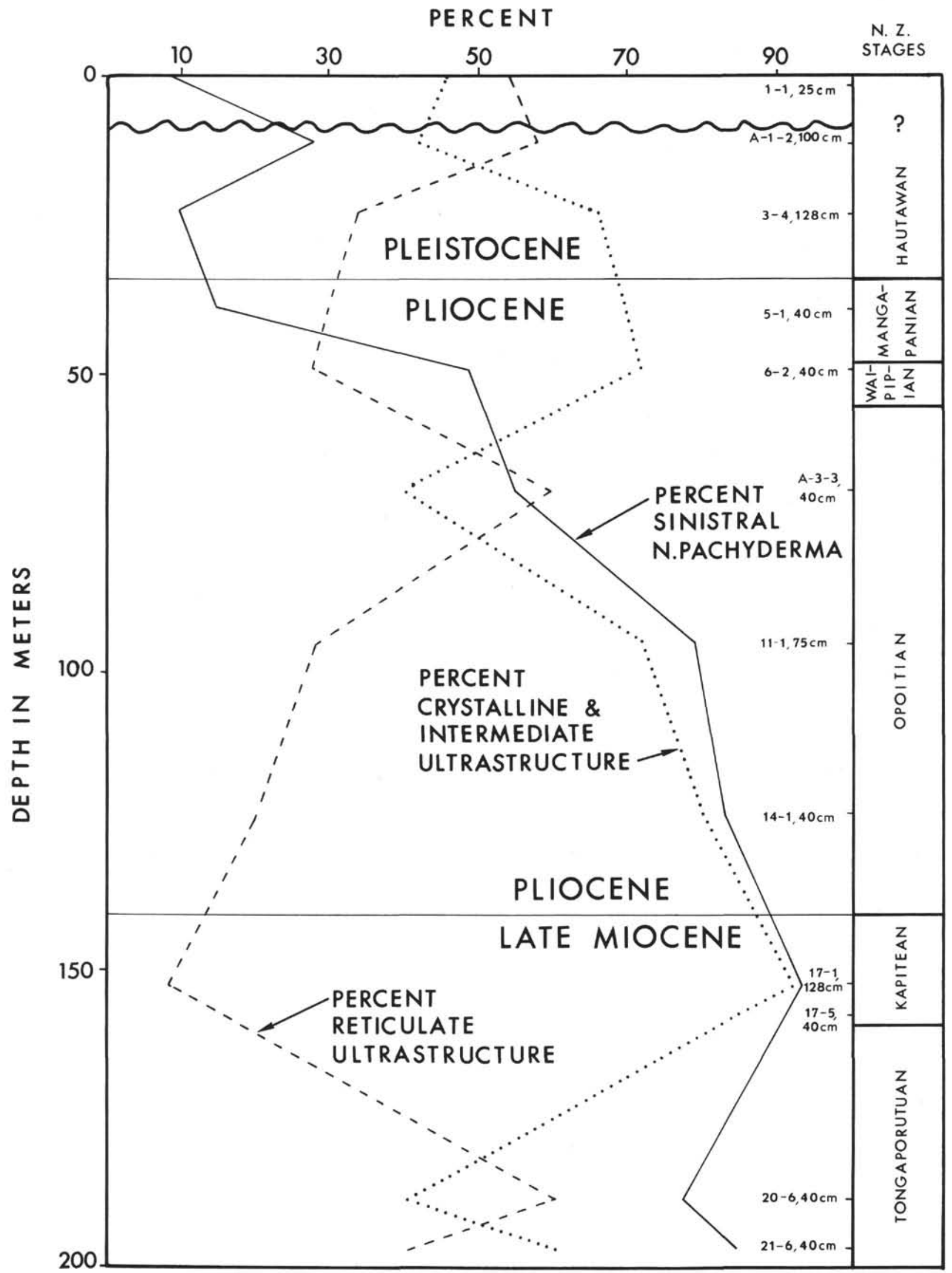

Figure 3. Coiling-ratio fluctuations of N. pachyderma (after Kennett and Vella, 1975) and surface ultrastructural variations of $\mathrm{N}$. pachyderma in DSDP Site 284. Ultrastructural variations correspond closely with paleoceanographic oscillations (see Figure 2) but coiling-ratio variations show little relation throughout most of sequence with ultrastructural and paleoceanographic oscillations. Other explanations as in Figure 2. 
in the late Miocene Tongaporutuan Stage indicating warm-water conditions are associated with dominantly sinistral populations which previously would have been considered to represent cool-water conditions.

Recently much significance has been given to possible ecologic and paleoecologic relations of kummerform individuals within planktonic foraminiferal populations (Berger, 1969; Hecht and Savin, 1970; Bé and van Donk, 1971). Kummerform individuals are highly dominant in the $N$. pachyderma populations examined (Table 1). We did not find any relations between frequencies of kummerform individuals of $N$. pachyderma and ultrastructural variation, coiling-ratios or frequency of $N$. pachyderma itself and hence water-mass fluctuations (Table 1). A difference does exist in the ultrastructure of the final chamber of kummerform and normalform individuals. Kummerform chambers have very immature (small crystals in crystalline forms, smoother surface, lacking ridges in reticulate forms) surface topography in comparison to the last chamber of normalforms which have surface ultrastructure much like earlier chambers. It is not clear whether the kummerform chamber in $N$. pachyderma represents a normal growth stage of each chamber within the ontogeny of the individual (Banerji et al., 1971) or if it reflects the growth limit of the individual (Olsson, 1973). The ultrastructural characteristics of kummerform chambers vary with the size of the chamber-small chambers having incipient ultrastructure, and successively larger chambers having ultrastructures more closely approaching the mature surface of the test. This supports the hypothesis of Banerji et al. (1971) that kummerform chambers reflect the successive growth stages of a single chamber. It seems that if the kummerform chamber did instead result from a stressed environment terminating growth of the individual, the ultrastructure would be more uniform in character in kummerform chambers of different sizes.

\section{DISCUSSION}

Srinivasan and Kennett $(1974,1975)$ and Kennett and Srinivasan (in press) have demonstrated in studies of Neogloboquadrina that reticulate ultrastructure is a primary surface ultrastructure while crystalline ultrastructure is of secondary nature. Reticulate ultrastructure is initially formed on all individuals of Neogloboquadrina from polar to equatorial water masses. Populations in certain water masses dominantly retain this ultrastructure with no further substantial surface alteration although some test thickening may occur by further deposition of microcrystals on interpore ridges. In populations from other water masses, reticulate ultrastructure becomes subordinate by the secondary development in most individuals of a calcite crust formed of distinct calcite crystals. This secondary encrustation produces thicker tests. Intermediate forms link the two ultrastructural types.

Kennett and Srinivasan (in press) in a nonquantitative study of $N$. pachyderma from different water masses have found that populations with reticulate ultrastructure dominate in Arctic and Subantarctic water masses while crystalline ultrastructure is dominant in other areas examined. Unfortunately, few samples were examined from cool subtropical waters adjacent to New
Zealand and hence the pattern of ultrastructural oscillations at Site 284 (Figure 2) could not be predicted from present-day ultrastructural patterns exhibited by the species. However, it would appear from the oscillations in ultrastructure at Site 284 that Recent southernmost cool subtropical waters should be marked by a dominance of crystalline forms and that the central part of the cool subtropical water mass should exhibit a slight dominance in forms with reticulate ultrastructure.

Previous work has shown that secondary calcification is primarily an adult characteristic within numerous species of planktonic foraminifera, taking place below certain critical water depths. Bé and Ericson (1963) demonstrated that secondary thickening in living Globorotalia truncatulinoides (d'Orbigny) occurs below 300 to 500 meters. Orr (1967) noted that critical increases in secondary calcification occur at depths of 120 to 700 meters for three other species of Globorotalia in the Gulf of Mexico. Bé (1960) observed that the development of crystalline thickening in $N$. pachyderma in Arctic waters occurs below about 200 meters while Boltovskoy (1971) observed that secondary thickening in this species is virtually complete at a depth of about 300 to 500 meters.

We, however, have now demonstrated that secondary crystalline thickening in Neogloboquadrina is not only an ontogenetic change related to increased water depths, but is related to regional water-mass changes in the oceans. Populations of Neogloboquadrina examined throughout the world's oceans by Srinivasan and Kennett (1974, 1975) and Kennett and Srinivasan (in press) were all obtained from depths greater than 1000 meters, which is well below the water depth at which secondary test thickening is reported to occur. Furthermore, we have demonstrated in the Site 284 sequence (Figure 2), which was deposited at depths greater than 1000 meters, that oscillations in the dominance of the two ultrastructural types is clearly related to paleoceanographic fluctuations. Thus, the presence or absence of secondary crystalline thickening in Neogloboquadrina reflects differences in the properties of water masses in which the specimens grew.

Srinivasan and Kennett (1975) examined the surface ultrastructure in Recent Neogloboquadrina dutertrei dutertrei from tropical to cool subtropical water mass and found that specimens of $N$. dutertrei dutertrei in tropical waters have thinner walls, high pore concentration, and pitted microcrystalline surfaces. Specimens from cool subtropical waters on the other hand are distinguished by thicker walls, low pore density, and rosette crystalline surfaces. Intermediate forms, with stellate crust, link these two groups in warm subtropical areas suggesting that these two ultrastructural types reflect phenotypic variation.

At the present time, virtually nothing is known about the environmental controls that effect secondary calcification within planktonic foraminifera. What are the characteristics of certain water masses that encourage secondary crystalline calcification in populations of $N$. pachyderma while in other water masses it fails to occur? Such questions can probably not be answered adequately until it is possible to conduct physiological experiments on planktonic foraminifera. 
In the meantime, however, surface ultrastructural changes in $N$. pachyderma can be utilized as water-mass markers. The record at Site 284 suggests that environmental-ultrastructural relations may have remained fairly constant through time as compared with other morphological characteristics such as the coiling ratio which definitely has undergone ecological changes with time (Figure 3).

\section{CONCLUSIONS}

1. Stereoscan examination of the test surface of $N$. pachyderma at DSDP Site 284 ranging from the late Miocene to Holocene or latest Pleistocene indicates two main surface ultrastructural types: reticulate forms characterized by pitted microcrystalline surface and thicker crystalline forms with test covered by distinct euhedral calcite rhombs.

2. Oscillations in the ratio of reticulate to crystalline ultrastructure in populations of $N$. pachyderma closely coincide with substantial fluctuations in past surface water masses recorded in the Site 284 sequence by Kennett and Vella (1975). Thinner walled, pitted, microcrystalline reticulate forms are dominant during warm-water episodes, while more thickened, crystalline forms predominate during cooler water episodes.

3. Ultrastructural differences in part reflect the degree of secondary calcification with reticulate microcrystalline ultrastructure preceding the formation of a thickening crystalline crust. Previous work has shown that substantial test thickening (secondary calcification) in planktonic foraminifera is primarily an adult characteristic taking place below certain critical water depths. Our work demonstrates that crystalline thickening in $N$. pachyderma is also water-mass related.

4. The environmental factors of certain water masses that actually control the degree of crystalline thickening in $N$. pachyderma are unknown. Despite this, surface ultrastructural change in populations can be utilized as a water-mass indicator throughout the late Cenozoic.

5. Oscillation in ultrastructural types indicates particularly severe climatic cooling episodes in the latest Miocene, the late Pliocene, and during the Pleistocene.

\section{ACKNOWLEDGMENTS}

We appreciate technical assistance provided by Mr. Donald Scales, Mr. Asaf Ashraf, Ms. Annette Doherty and secretarial assistance by M. Nancy Meader.

The scanning electron microscope facility at the University of Rhode Island was established with the assistance of a grant from the National Science Foundation (Oceanography Division; GA-28905). This research was supported by National Science Foundation Grant GA-35252.

\section{REFERENCES}

Bandy, O.L., 1959. The geologic significance of coiling ratios in the foraminifer Globigerina pachyderma (Ehrenberg): Geol. Soc. Am. Bull., v. 70, p. 1708 (abstract).

1960. The geologic significance of coiling ratios in the foraminifer Globigerina pachyderma (Ehrenberg): J. Paleontol., v. 34 , p. 671 .

Banerji, R.K., Schafer, C.T., and Vine, R., 1971. Environmental relationships and distribution of planktonic foraminifera in the equatorial and northern Pacific waters: Dept. Energy, Mines, Res., Mar. Sci. Branch, Atlantic Ocean Lab., Rept. 1971-7.

Bartlett, G.A., 1967. Scanning electron microscope: potentials in the morphology of micro-organisms: Science, v. 158 , p. 1318.

Bé, A.W.H., 1960. Some observations on Arctic planktonic foraminifera: Cushman Found. Foram. Res. Contrib. v. 11, pt. 2, p. 65 .

, 1968. Shell porosity of Recent planktonic foraminifera as a climatic index: Science, v. 161, p. 881 .

Bé, A.W.H. and Ericson, D.B., 1963. Aspects of calcification in planktonic foraminifera (sarcodina). In Comparative biology of calcified tissues: Ann. N.Y. Acad. Sci., v. 109, p. 65.

Bé, A.W.H. and van Donk, J., 1971. Oxygen-18 studies of Recent planktonic foraminifera: Science, v. 173, p. 167.

Berger, W.H., 1969. Kummerform foraminifera as clues to oceanic environments (abstract: Am. Assol. Petrol. Geol. Bull., v. 53, p. 706 .

Boltovskoy, E., 1971. Planktonic foraminiferal assemblages of the Epipelagic Zone and their Thanatocoenoses. In Funnel, B.M. and Reidel, W.R. (Eds.), The Micropaleontology of oceans: Cambridge (Cambridge University Press), p. 277.

Cifelli, R., 1973. Observations on Globigerina pachyderma Ehrenberg) and Globigerina incompta. Cifelli from the North Atlantic: J. Foram, Res., v. 3, p. 157.

Collen, J.D. and Vella, P., 1973. Pliocene planktonic foraminifera, Southern North Island, New Zealand: J. Foram. Res., v. 3, p. 13.

Deacon, G.E.R., 1937. Hydrology of the Southern Ocean: "Discovery" Rept. 15, p. 1-124.

Ericson, D.B., 1959. Coiling direction of Globigerina pachyder$m a$ as a climatic index: Science, v. 130, p. 219.

Fleming, C.A., 1944. Molluscan evidence of Pliocene climatic change in New Zealand: Roy. Soc. New Zealand Trans., v. 74, p. 207.

Frerichs, W.E., Heiman, M.E., Borgman, L.E., and Bé, A.W.H., 1972. Latitudinal variations in planktonic foraminiferal test porosity: Part 1. optical studies: J. Foram. Res., v. 2, p. 6.

Garner, D.M., 1954. Sea surface temperature in the Southwest Pacific Ocean from 1949 to 1952: New Zealand J. Sci Tech. B., v. 36 , p. 285.

Hecht, A.D. and Savin, S.M., 1970. Oxygen-18 studies on Recent planktonic foraminifera: Comparisons of phenotypes and test parts: Science, v. 170 , p. 69.

Hunkins, K., Bé, A.W.H., Opdyke, N.D., and Mathieu, G., 1971. The late Cenozoic history of the Arctic Ocean. In Turekian, K.K. (Ed.), The late Cenozoic glacial ages: New Haven (Yale University Press), p. 215.

Ingle, J.C., Jr., 1967. Foraminiferal biofacies variation and the Miocene-Pliocene boundary in Southern California: Am. Paleontol. Bull., v. 52.

Jenkins, D.G., 1967. Recent distribution, origin, and coiling ratio changes in Globigerina pachyderma (Ehrenberg). Micropaleontology, v. 13, n. 2, p. 195.

Kennett, J.P., 1967. Paleo-oceanographic aspects of the foraminiferal zonation in the upper Miocene-lower Pliocene of New Zealand: Internatl. Congr. 4th Bologna. Gior. Geol. v. 35, p. 143.

Kennett, J.P. and Srinivasan, M.S., in press. Surface ultrastructural variation in Neogloboquadrina pachyderma (Ehrenberg): phenotypic variation and phylogeny in the late Cenozoic. "O.L. Bandy Memorial Volume": Kolpack, R. and Gorsline, D. (Eds.).

Kennett, J.P. and Vella, p., 1975. Late Cenozoic plankton foraminifera and paleoceanography at DSDP Site 284 in 
the cool subtropical South Pacific. In Kennett, J.P., Houtz, R.E., et al., Initial Reports of the Deep-Sea Drilling Project, Volume 29: Washington (U.S. Government Printing Office), p. 769-800.

Kennett, J.P. and Watkins, N.D., 1975. Late Miocene-early Pliocene paleomagnetic stratigraphy in New Zealand: Geol. Soc. Am. Bull., v. 85 , p. 1385 .

Kennett, J.P., Watkins, N.D., and Vella, P., 1971. Paleomagnetic chronology of Pliocene-Early Pleistocene climates and the Plio-Pleistocene boundary in New Zealand: Science, v. 171 , p. 276.

Lipps, J.H., 1966. Wall structure, systematics, and phylogeny studies of Cenozic planktonic foraminifera: J. Paleontol., v. 40, p. 1257.

McGowran, B., 1968. Reclassification of early Tertiary Globorotalia: Micropaleontology, v. 14, p. 179.

Olsson, R.K., 1973. What is a kummerform planktonic foraminifer?: J. Paleontol., v. 47, p. 327.

Orr, W.N., 1967. Secondary calcification in the foraminfera genus Globorotalia: Science, v. 157, p. 1554.

Shackleton, N.J. and Kennett, J.P., 1975. Late Cenozoic oxygen and carbon isotopic changes at DSDP Site 284: implications for glacial history of the Northern Hemisphere and Antarctica. In Kennett, J.P., Houtz, R.E., et al., Initial
Reports of the Deep Sea Drilling Project, Volume 29: Washington (U.S. Government Printing Office), p. 801808.

Srinivasan, M.S. and Kennett, J.P., 1974. SEM ultrastructural variation in planktonic foraminifera: value in evolutionary and phenotypic studies: Am. Assoc. Petrol. Geol. Bull., v. 1, p. 86.

1975. Evolution and phenotypic variation in the Late Cenozoic Neogloboquadrina dutertrei plexus. In Takayanagi, Y. and Saito, T. (Eds.), Prof. Asano Commemoration Volume: New York (Micropaleontology Press).

Tappan, H. and Lipps, J.H., 1966. Wall structures, classifications, and evolution in planktonic foraminifera: Am. Assoc. Petrol. Geol. Bull., v. 50, p. 637.

Vilks, G. and Walker, D.A., 1974. Morphology of Orbulina universa d'Orbigny, in relation to other spinose planktonic foraminifera: J. Foram, Res., v. 4, p. 1.

Walker, D.A. and Vilks, G., 1973. Spinal ultrastructure of the planktonic foraminifers Hastigerina Thomson and Globigerinella Cushman: J. Foram. Res. v. 3, p. 196.

Wiles, W.W., 1967. Pleistocene changes in the pore concentration of a planktonic foraminiferal species from the Pacific Ocean: Prog Oceanogr., v. 4, p. 153. 



\section{PLATE 1}

Figures 1-9 Reticulate form of Neogloboquadrina pachyderma (Ehrenberg).

1. Ventral view; 284-20-6, $40 \mathrm{~cm} ; \times 380$.

2. Ventral view; $284-21-6,40 \mathrm{~cm} ; \times 490$.

3. Ventral view; $284-6-2,40 \mathrm{~cm} ; \times 250$.

4. Surface of final chamber of dextral specimen, showing circular central pores, smooth, microcrystalline wall, and deep pore pits. 284$3-4,128 \mathrm{~cm} ; \times 2500$.

5. Surface of final chamber of dextral specimen. Note the discrete tubercles surrounding the pores. 284-11-1, $75 \mathrm{~cm} ; \times 2300$.

6. Surface of final chamber of sinistral form with circular central pores, smooth, microcrystalline wall, and funnel-shaped pore pits. 284-17-1, 128 $\mathrm{cm} ; \times 2000$.

7. Surface of penultimate chamber of Figure 2. Note the flat pore bases and the steeply rising ridges. Occasionally more than one pore is enclosed in a single pore pit; $\times 2500$.

8. Surface of the earliest chamber in the last whorl of sinistral form. Note the typical funnelshaped pore pits and smooth microcrystalline interpore area. 284-6-2, $40 \mathrm{~cm}$; $\times 3100$.

9. Surface of the earliest chamber in the last whorl of Figure 3. The topography of the earliest chamber is much coarser due to irregular growth of tubercles on the interpore region; $\times$ 3200 . 


\section{PLATE 1}
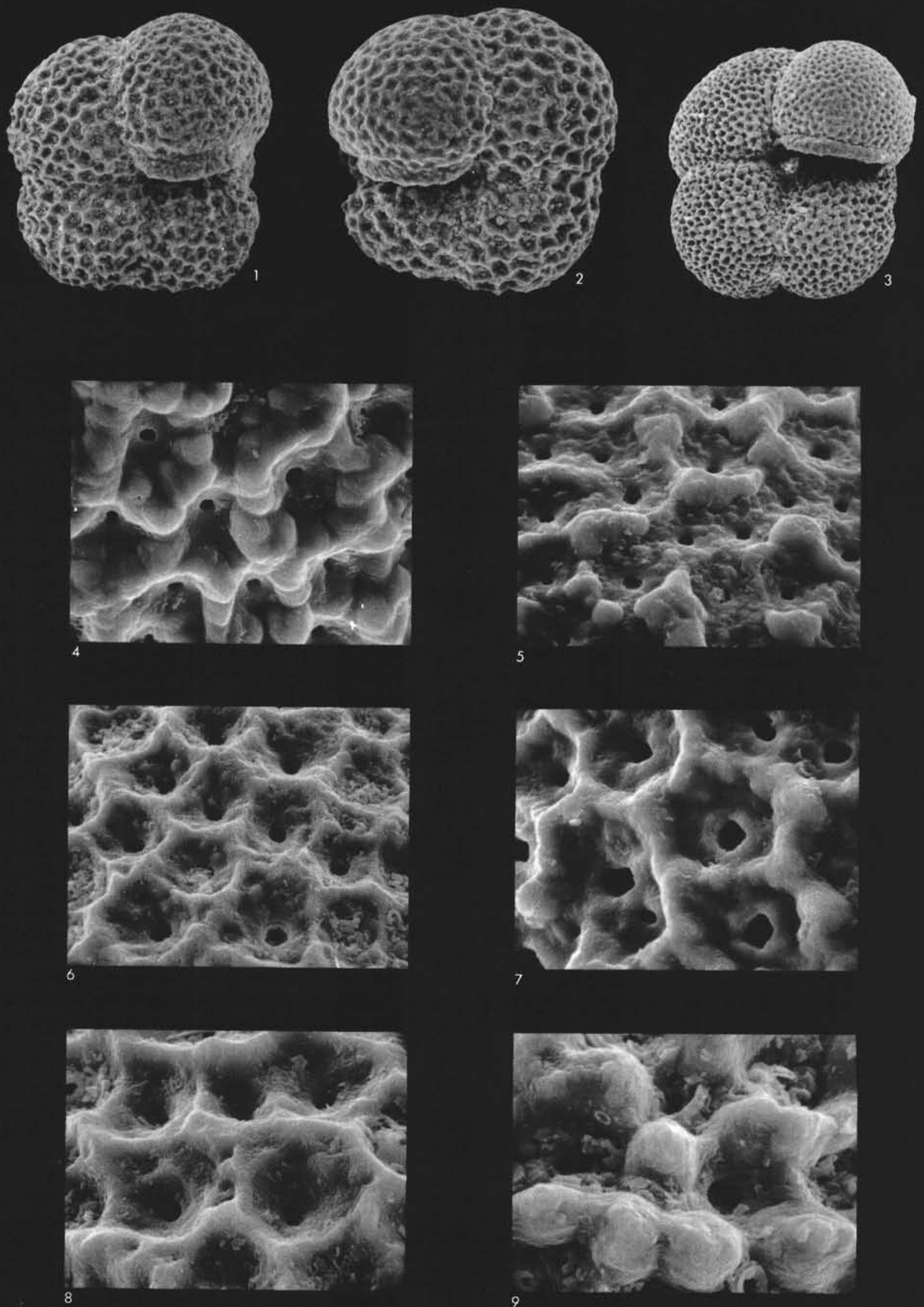


\section{PLATE 2}

Crystalline form of Neogloboquadrina pachyderma (Ehrenberg)

Figures 1-9 1. Ventral view; 284-6-2, $40 \mathrm{~cm} ; \times 340$.

2. Ventral view; same location as Figure $1 ; \times 400$.

3. Ventral view; $284-17-1,128 \mathrm{~cm} ; \times 340$.

4. Ventral view; same location as Figure $3 ; \times 340$. Note that penultimate chamber shows reticulate surface, whereas all other chambers have crystalline surface. Such forms have been classified as intermediate.

5. Surface of the earliest Chamber in last whorl of sinistral form. Note the rosette arrangement of calcite crystals. Same location as Figure 3; $\times$ 1000.

6. Enlarged view of the apertural rim and a part of the final chamber of a kummerform dextral specimen. Same location as Figure 3; $\times 1300$.

7. Surface of final chamber of dextral kummerform specimen. Location same as Figure 3; $\times 4700$.

8. Surface of the penultimate chamber of sinistral form. Note the calcite rhombohedra clustering around pores. The interpenetrating crystal twins produce a stellate crust. Location same as Figure $3 ; \times 2000$.

9. Enlarged view of the second chamber from the earliest in the last whorl of a dextral form. Note that the interpenetrating crystal twins produce a stellate crust. The coarse growth facets of the rhombohedrons are distinct, and also note the irregular-shaped pores between the stellate structures. Location same as Figure 3; $\times 5200$. 
PLATE 2
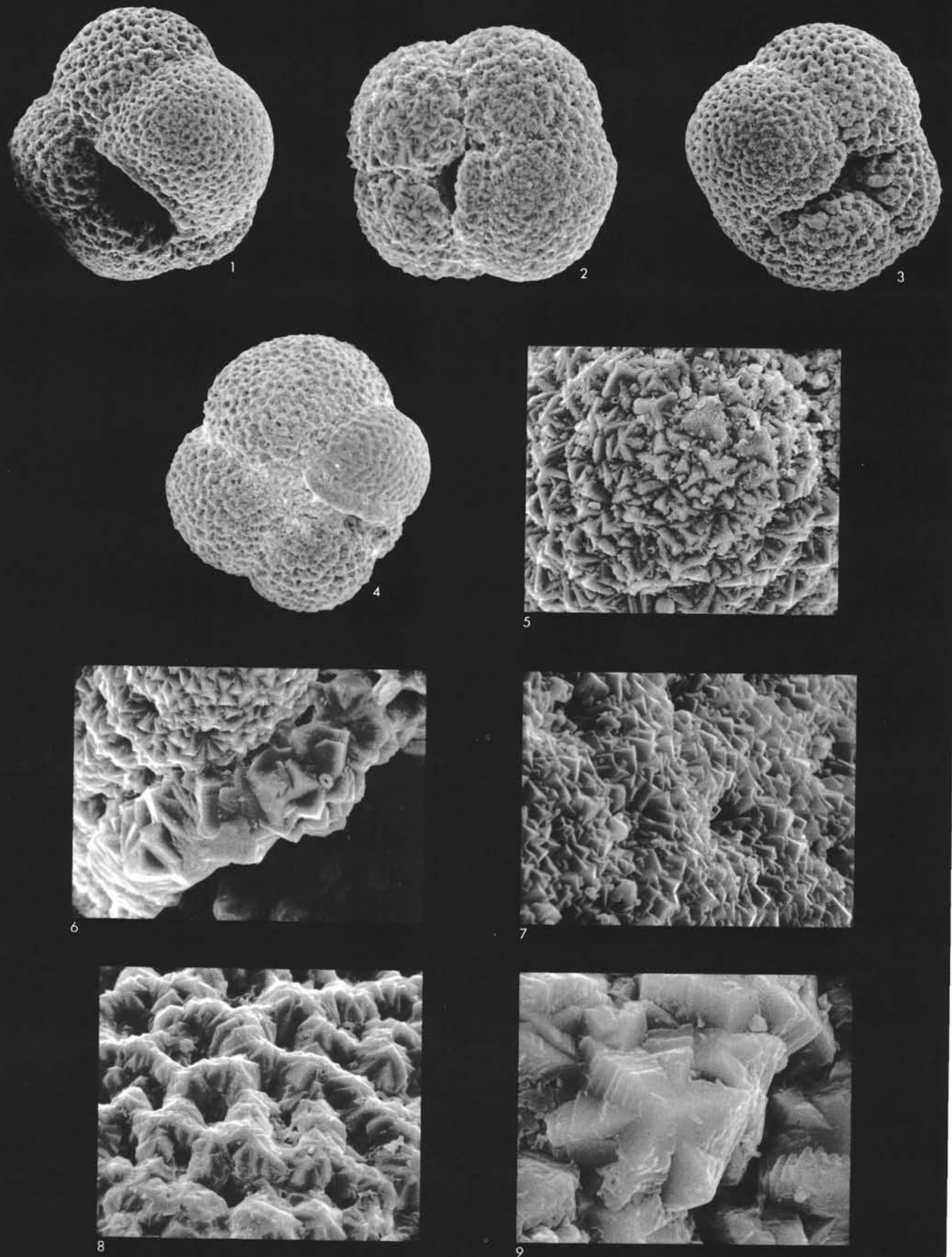